\title{
Kwaliteit van gediplomeerde schoolverlaters van creatieve MBO-opleidingen
}

Citation for published version (APA):

Coenen, J. B., Huijgen, T. G., Meng, C. M., \& Ramaekers, G. W. M. (2010). Kwaliteit van gediplomeerde schoolverlaters van creatieve $M B O$-opleidingen. Researchcentrum voor Onderwijs en Arbeidsmarkt, Faculteit der Economische Wetenschappen. ROA Reports No. 6 https://doi.org/10.26481/umarep.2010006

Document status and date:

Published: 01/01/2010

DOI:

10.26481/umarep.2010006

Document Version:

Publisher's PDF, also known as Version of record

\section{Please check the document version of this publication:}

- A submitted manuscript is the version of the article upon submission and before peer-review. There can be important differences between the submitted version and the official published version of record.

People interested in the research are advised to contact the author for the final version of the publication, or visit the DOI to the publisher's website.

- The final author version and the galley proof are versions of the publication after peer review.

- The final published version features the final layout of the paper including the volume, issue and page numbers.

Link to publication

\footnotetext{
General rights rights.

- You may freely distribute the URL identifying the publication in the public portal. please follow below link for the End User Agreement:

www.umlib.nl/taverne-license

Take down policy

If you believe that this document breaches copyright please contact us at:

repository@maastrichtuniversity.nl

providing details and we will investigate your claim.
}

Copyright and moral rights for the publications made accessible in the public portal are retained by the authors and/or other copyright owners and it is a condition of accessing publications that users recognise and abide by the legal requirements associated with these

- Users may download and print one copy of any publication from the public portal for the purpose of private study or research.

- You may not further distribute the material or use it for any profit-making activity or commercial gain

If the publication is distributed under the terms of Article $25 \mathrm{fa}$ of the Dutch Copyright Act, indicated by the "Taverne" license above, 


\title{
Kwaliteit van gediplomeerde schoolverlaters van creatieve MBO-opleidingen
}

\author{
Johan Coenen \\ Timo Huijgen \\ Christoph Meng \\ Ger Ramaekers
}

ROA-R-2010/6 


\section{Colofon}

(C) Researchcentrum voor Onderwijs en Arbeidsmarkt (ROA). Niets uit deze uitgave mag op enige manier worden verveelvoudigd zonder voorafgaande schriftelijke toestemming van de directeur van het ROA.

\section{Researchcentrum voor Onderwijs en Arbeidsmarkt}

School of Business and Economics

Maastricht University

\section{Vormgeving}

ROA secretariaat, Maastricht

email: secretary-roa-sbe@maastrichtuniversity.nl

website: www.roa.nl

ISBN: 978-90-532I-487-9

juni 2010 


\section{Inhoud}

Samenvatting

1 Inleiding 1

2 Kwaliteit van schoolverlaters 5

$\begin{array}{lll}3 & \text { Kwalificatie } & 7\end{array}$

4 Selectie 11

5 Kwalificerende vervolgtrajecten $\quad 15$

$\begin{array}{ll}5.1 \text { Allocatie } & 15\end{array}$

$\begin{array}{ll}5.2 \text { Rendement } & 17\end{array}$

6 Intrede op de arbeidsmarkt $\quad 19$

6.1 Allocatie 19

6.2 Extern rendement 22

$\begin{array}{lll}7 & \text { Tevredenheid achteraf } & 27\end{array}$

$\begin{array}{lr}\text { Literatuur } & 29\end{array}$ 


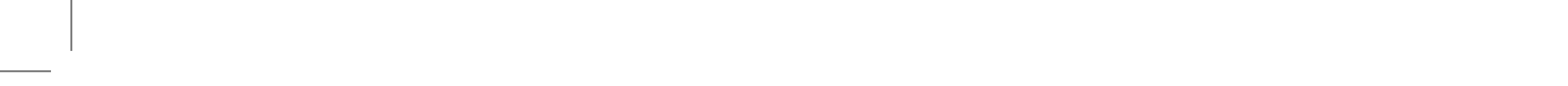




\section{Samenvatting}

Ten aanzien van het oordeel over de gevolgde opleiding zijn gediplomeerde schoolverlaters van creatieve BOL-opleidingen vergeleken met gediplomeerde schoolverlaters van andere BOL-opleidingen:

- iets minder vaak tevreden over enkele aspecten van hun kwalificatie (breedte en diepgang van hun opleiding evenals hun startbekwaamheid);

- iets minder vaak tevreden over enkele aspecten van de selectiviteit van hun opleiding (moeilijkheidsgraad van hun opleiding en voldoende toetsen op inzicht).

Kijken we naar de doorstroom naar vervolgonderwijs, dan zien we dat de gediplomeerde schoolverlaters van creatieve BOL-opleidingen vergeleken met gediplomeerde schoolverlaters van andere BOL-opleidingen iets minder vaak doorstromen naar vervolgonderwijs dat bovendien iets minder vaak verwant is aan hun opleiding, en iets minder vaak bevorderd worden naar het tweede leerjaar van de vervolgopleiding.

Met betrekking tot het rendement op de arbeidsmarkt komt naar voren dat gediplomeerde schoolverlaters van creatieve BOL-opleidingen vergeleken met gediplomeerde schoolverlaters van andere BOL-opleidingen:

- zich met minder succes (vaker werkloos) en daarom wellicht ook minder vaak aanbieden op de arbeidsmarkt, waar zij langer naar werk (moeten) zoeken;

- vaker in voltijd werken en daarom, ondanks hun lager uurloon, toch een gelijk maandloon hebben.

Wat de allocatie op de arbeidsmarkt betreft zien we dat de gediplomeerde schoolverlaters van creatieve BOL-opleidingen vergeleken met gediplomeerde schoolverlaters van andere BOL-opleidingen:

- iets minder vaak terecht komen in banen die aansluiten op het niveau en de richting van hun opleiding;

- daarmee ook iets minder vaak hun kennis en vaardigheden in hun werk kunnen benutten;

- iets minder vaak tevreden zijn over de aansluiting van hun werk op hun opleiding, en iets minder vaak tevreden zijn over hun functie.

Wellicht speelt bij de resultaten met betrekking tot de allocatie en het rendement op de arbeidsmarkt een rol dat gediplomeerde schoolverlaters van creatieve opleidingen in de BOL iets vatbaarder zijn voor een economische baisse dan gediplomeerde schoolverlaters van andere BOL-opleidingen. 
Bovengenoemde verschillen laten overigens onverlet dat de gediplomeerde schoolverlaters van de creatief gerichte opleidingen in de BOL, achteraf bezien, even vaak tevreden zijn over de destijds gemaakte opleidingskeuze dan gediplomeerde schoolverlaters van de overige opleidingen in de BOL. 


\section{Inleiding}

Sinds I99I voert het Researchcentrum voor Onderwijs en Arbeidsmarkt (ROA) van Maastricht University in samenwerking met DESAN Research Solutions jaarlijks enkele grootschalige onderzoeken uit onder recente schoolverlaters. Hiertoe behoort onder meer de BVE-Monitor, een enquête onder schoolverlaters van de beroepsopleidende (BOL) en beroepsbegeleidende leerweg (BBL) van het secundair beroepsonderwijs. Het Ministerie van OCW heeft het ROA verzocht om in meting 2009 alle gediplomeerde schoolverlaters te benaderen van de door haar aangegeven creatief gerichte opleidingen in het MBO-BOL. De hier gepresenteerde gegevens hebben betrekking op het eind 2009 uitgevoerde onderzoek onder schoolverlaters MBO-BOL die in schooljaar 2007-2008 hun diploma hebben behaald, dat wil zeggen ongeveer anderhalf jaar na het voltooien van de opleiding. Bedacht moet worden dat deze schoolverlaters weliswaar nog net voor de economische crisis hun diploma hebben behaald, maar dat eind 2009 - het moment waarop de hier gepresenteerde cijfers betrekking hebben - Nederland zich in een economische malaise bevond.

Voor de volledige resultaten van de in 2009 uitgevoerde meting wordt verwezen naar het ROA-rapport Schoolverlaters tussen onderwijs en arbeidsmarkt 2009 en de website www.roa.unimaas.nl/kernciffers.htm.

De creatieve opleidingen in het MBO-BOL kunnen worden ingedeeld in de volgende categorieën:

- Techniek (Goud- en zilversmeden)

- Mode en Kleding

- Theater en Podium (techniek)

- Media en Grafische Vormgeving.

Schema I laat zien welke opleidingen hier onder vallen.

\section{Schema 1}

Clustering van creatieve opleidingen in het MBO-BOL

Goud- en Zilversmeden

BOL BB Productiemedewerker goud- en zilversmeden

BOL ZB Goudsmid

BOL ZB Juwelier

BOL ZB Goud- en zilversmeden (Basisgoudsmid) 


\section{Schema 1 (vervolg)}

Clustering van creatieve opleidingen in het MBO-BOL

BOL MKF Goudsmid/ondernemer

BOL MKF Zilversmid/ondernemer

BOL MKF Juwelier/ondernemer

BOL MKF Goud- en zilversmeden

BOL Specialist Goudsmid specialist

Mode en Kleding

BOL AB Assistent medewerker naaizaal

BOL BB Uitvoerend medewerker naai-/perszaal

BOL BB Uitvoerend medewerker kleinvak maatkleding

BOL BB Medewerker mode/maatkleding (Basismedewerker mode/maatkleding)

BOL ZB Medewerker grootvak maatkleding

BOL MKF Ontwikkeling (confectie)

BOL MKF Commercie (confectie)

BOL MKF Productie (confectie)

BOL MKF Ondernemer/middenkader medewerker breedvak maatkleding

BOL MKF Medewerker Mode en Kleding

Theater en Podiumtechniek

BOL BB Podium- en Evenementtechniek

BOL ZB Theatertechnicus

BOL ZB Podium- en Evenementtechniek

BOL MKF Podium- en Evenementtechniek (podiumtechnicus toneel)

BOL MKF Artiest (drama)

BOL MKF Artiest dans

BOL MKF Artiest musical

BOL MKF Artiest (muziek)

Media en Grafische Vormgeving

BOL MKF Vormgever reclame, presentatie en communicatie

BOL MKF Mediatechnologie

BOL MKF Grafisch vormgever

BOL MKF Grafisch management

BOL MKF Multimedia vormgever

BOL MKF IT Mediaproductie

BOL MKF Vormgever ruimtepresentatie en communicatie

BOL MKF Gaming (gamedesigner)

BOL MKF Fotonica

\section{Omvang van de steekproef en respons}

Tabel I laat zien dat de respons over de hele linie circa $20 \%$ bedroeg. Van de creatief gerichte opleidingen in het mbo-bol zijn de opleidingen Mode en Kleding en vooral de opleidingen Media en Grafische Vormgeving duidelijk het grootst wat het aantal gediplomeerden in de steekproef betreft (tabel I). Omdat de aantallen gediplomeerden bij 
de opleidingen voor Goud- en zilversmeden en Theater en Podium(techniek) beduidend kleiner zijn, dienen de resultaten waarbij een onderscheid wordt gemaakt tussen degenen die zich op de arbeidsmarkt hebben aangeboden en degenen die verder zijn gaan leren voor deze kleine opleidingen onder het grootste voorbehoud te worden geïnterpreteerd. Om deze reden worden de resultaten voor deze kleine opleidingen dan ook niet besproken bij de tabellen waarbij alleen data van degenen die vervolgonderwijs zijn gaan volgen of degenen die de arbeidsmarkt hebben betreden, worden gebruikt.

\section{Persoonskenmerken}

Tabel I typeert de gediplomeerden MBO-BOL aan de hand van drie persoonskenmerken, namelijk leeftijd, geslacht en etniciteit.

Wat de gemiddelde leeftijd betreft zijn de gediplomeerde Goud- en Zilversmeden duidelijk ouder dan de andere (creatieve) MBO-BOL opleidingen. Vrouwen zijn duidelijk oververtegenwoordigd in de opleidingen voor Goud- en zilversmeden en vooral de Mode en Kleding opleidingen, en ondervertegenwoordigd in de opleidingen Theater en Podiumtechniek. Wat het aandeel van allochtonen betreft blijkt dat westerse allochtonen relatief sterk zijn vertegenwoordigd in de Theater- en Podiumopleidingen en niet-westerse allochtonen in de Mode- en Kledingopleidingen.

Tabel 1

Respons en persoonskenmerken

\begin{tabular}{lcccccr|} 
& $\begin{array}{c}\text { Goud- en } \\
\text { zilversmeden }\end{array}$ & $\begin{array}{c}\text { Mode en } \\
\text { kleding }\end{array}$ & $\begin{array}{c}\text { Theater en } \\
\text { podium- } \\
\text { techniek }\end{array}$ & $\begin{array}{c}\text { Media en } \\
\text { grafische } \\
\text { vormgeving }\end{array}$ & $\begin{array}{c}\text { Creatieve } \\
\text { opleidingen } \\
\text { totaal }\end{array}$ & $\begin{array}{c}\text { Overig bol } \\
\text { totaal }\end{array}$ \\
\hline Aantal benaderd & 128 & 699 & 163 & 1893 & 2883 & 16267 \\
\hline Responspercentage & 21 & 18 & 21 & 20 & 20 & 20 \\
\hline Respondenten & 26 & 128 & 34 & 383 & 571 & 3309 \\
\hline Gemiddelde leeftijd & 31,6 & 22,2 & 22 & 22,5 & 22,8 & 22 \\
\hline Percentage man & 19 & 4 & 68 & 54 & 45 & 44 \\
\% autochtoon & 95 & 64 & 81 & 87 & 83 & 78 \\
\hline \% westerse allochtoon & 0 & 5 & 13 & 7 & 7 & 4 \\
\hline \% niet westerse allochtoon & 5 & 31 & 6 & 6 & 10 & 18
\end{tabular}




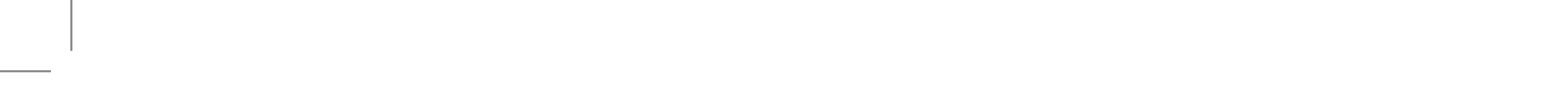




\section{Kwaliteit van schoolverlaters}

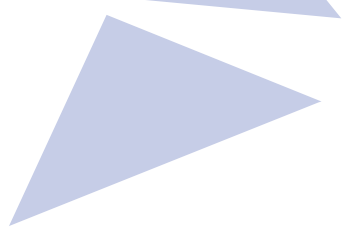

Als we praten over kwaliteit kunnen we een onderscheid maken tussen doeltreffendheid en doelmatigheid (Onderwijsraad, 1999). Doeltreffendheid zegt iets over de mate waarin het onderwijs de haar toegeschreven functies vervult en is een indicator voor de effectiviteit van het onderwijs. Doelmatigheid zegt iets over de kosten efficiëntie waarmee het onderwijs deze functies vervult. Het merendeel van de door ons onderzochte kwaliteitsaspecten heeft betrekking op de doeltreffendheid. We onderscheiden daarbij de volgende functies: de kwalificatiefunctie, de selectiefunctie en de allocatiefunctie (Peschar \& Wesselingh, 200I).

\section{Kwalificatiefunctie}

Voor een goede doorstroom naar het vervolgonderwijs of de arbeidsmarkt is het noodzakelijk dat de schoolverlater in voldoende mate beschikt over de vereiste competenties. Bij de kwalificatiefunctie van het onderwijs gaat het om de vraag in hoeverre het onderwijs er in is geslaagd om schoolverlaters met deze competenties toe te rusten. Hierbij gaat het niet alleen om de startbekwaamheid van de schoolverlaters (de korte termijn doelstelling van het onderwijs), maar ook om de mate waarin de opleiding een voldoende basis heeft geboden voor de verdere ontwikkeling van 'novice' tot 'expert' (ontwikkelpotentieel) en voor de mate waarin de opleiding heeft bijgedragen aan de algehele 'employability' van de schoolverlater (de lange termijn doelstellingen).

\section{Selectiefunctie}

De betrouwbaarheid waarmee het onderwijs haar studenten beoordeelt op de aanwezige competenties en op grond hiervan een eindniveau certificeert is van groot belang. De legitimering van de kwalificatiefunctie van het onderwijs is namelijk voor een groot deel gelegen in deze betrouwbaarheid. Zowel onderwijsinstellingen zelf als bijvoorbeeld werkgevers zullen er op moeten kunnen vertrouwen dat een schoolverlater met een bepaald eindcertificaat ook daadwerkelijk beschikt over de competenties die bij het betreffende diploma horen. Over deze betrouwbaarheid van de selectie zijn echter maar weinig gegevens beschikbaar. In dit rapport maken we gebruik van oordelen van de schoolverlaters en afgestudeerden zelf over de selectiviteit van de opleiding. 


\section{Allocatiefunctie}

De allocatiefunctie richt zich op de ondersteuning bij de transitie naar de vervolgopleiding en de arbeidsmarkt en op de aansluiting tussen de gekozen vervolgstudie of de gevonden baan en de gevolgde opleiding. Dit kan onder andere door te kijken in hoeverre het onderwijs de afgestudeerden voldoende heeft voorgelicht over de mogelijkheden in het vervolgonderwijs en de arbeidsmarkt na het verlaten van de studie. Met betrekking tot de aansluiting kan bijvoorbeeld gekeken worden naar de vraag in hoeverre men werk gevonden heeft dat wat betreft niveau en richting aansluit bij de afgeronde studie.

\section{Extern rendement}

Het externe rendement van onderwijs kan worden gezien als een van de belangrijkste doelmatigheidsaspecten. Het gaat daarbij om de verhouding tussen de kosten en de opbrengsten die door zowel individuen als de overheid gerealiseerd worden. In dit rapport beperken we ons tot het externe rendement op individueel niveau. Voor degenen die zich aanbieden op de arbeidsmarkt kijken we daarbij naar een drietal indicatoren te weten: (I) het werkloosheidspercentage 1,5 jaar na het verlaten van de opleiding, (2) het bruto uurloon en maandloon I,5 jaar na het verlaten van de opleiding en (3) de carrièremogelijkheden van de gevonden baan. Wat het externe rendement betreft voor schoolverlaters die naar een vervolgopleiding doorstromen, kijken we (I) naar het percentage van hen dat in de eerste anderhalf jaar alweer gestopt of van studie gewisseld is en (2) naar het percentage van hen dat bevorderd is naar het tweede/volgende leer- of studiejaar.

\section{Tevredenheid achteraf}

Met name voor onderwijsinstellingen is het van belang te weten in welke mate de gediplomeerde uitstroom achteraf weer voor dezelfde opleiding en dezelfde school zou kiezen. Met andere woorden, zijn de schoolverlaters tevreden over de gekozen opleiding en de gekozen school? Schoolverlaters wordt daarom altijd de vraag voorgelegd of ze achteraf gezien opnieuw dezelfde opleiding zouden kiezen. De tevredenheid wordt bepaald door de mate waarin de ervaringen achteraf van de schoolverlaters met betrekking tot hun opleiding overeenkomen met hun verwachtingen vooraf. Omdat dit oordeel op een groot aantal aspecten gebaseerd is geeft het als het ware een samenvattend oordeel over de kwaliteit van het onderwijs. 


\section{Kwalificatie}

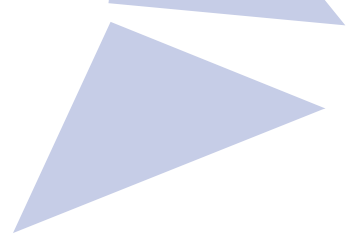

Voor een succesvolle start op de arbeidsmarkt of het met succes kunnen volgen van een vervolgstudie is het een eerste vereiste dat de schoolverlater beschikt over de benodigde competenties. In hoeverre het onderwijs erin geslaagd is de schoolverlater de benodigde competenties bij te brengen is het aandachtspunt van het kwalificatieaspect. Voor gediplomeerden die naar de arbeidsmarkt doorstromen, is hierbij niet alleen relevant of de opleiding hen startbekwaam heeft gemaakt (de korte termijn doelstelling van het onderwijs), maar ook of de opleiding een goede basis is voor de verdere ontwikkeling van 'novice' tot 'expert' (ontwikkelpotentieel) en voor de algehele 'employability' van de gediplomeerden (de lange termijn doelstelling).

Om hier inzicht in te krijgen is de gediplomeerden gevraagd de afgeronde opleiding te beoordelen op een viertal aspecten: (I) de breedte van de opleiding (te smal <--> te breed), (2) de diepgang van de opleiding (te weinig diepgang $<->>$ te veel diepgang), (3) de mate waarin de opleiding een goede basis biedt om te starten op de arbeidsmarkt en (4) de mate waarin de opleiding een goede basis biedt om kennis en vaardigheden verder te ontwikkelen. Daarbij geeft het item over de start op de arbeidsmarkt (3) een inschatting van het oordeel van de gediplomeerden over de korte termijn doelstelling van het onderwijs. De mate waarin de opleiding een goede basis biedt voor het verder ontwikkelen van kennis en vaardigheden (4) zegt iets over de lange termijn doelstelling.

\section{Breedte opleiding}

Gemiddeld vond I/8 van de gediplomeerden van de creatieve BOL-opleidingen zijn/ haar opleiding te smal; I4\% van hen vond de opleiding te breed. Met andere woorden driekwart $(74 \%)$ van alle gediplomeerden van de creatieve opleidingen vond de opleiding goed qua breedte. Gediplomeerden van drie van de vier opleidingscategorieën vonden hun opleiding echter veel vaker te smal dan te breed. Dit gold voor de gediplomeerden goud/zilversmeden, de gediplomeerden Theater en Podiumtechniek en de gediplomeerden Mode en Kleding. De opleidingscategorie Media en Grafische Vormgeving wordt daarentegen vaker als een brede dan als een smalle opleiding beoordeeld: Bij de overige BOL-opleidingen vond 7,5\% de opleiding te smal en II $\%$ de opleiding te breed. Deze gediplomeerden zijn dus iets vaker tevreden over de breedte van hun opleiding dan de gediplomeerden van de creatieve opleidingen. 
Tabel 2

Aandeel gediplomeerden dat de opleiding te smal ( 1 of 2 op een zevenpuntsschaal) of te breed (6 of 7 op een zevenpuntsschaal) vond

\begin{tabular}{lcc|}
\hline$\%$ & te smal & te breed \\
\hline Goud- en zilversmeden & 33,0 & 3,1 \\
\hline Mode en Kleding & 17,5 & 6,5 \\
\hline Theater en Podiumtechniek & 23,2 & 1,3 \\
\hline Media en Grafische Vormgeving & 8,5 & 17,9 \\
\hline Totaal creatieve MBO-opleidingen & 12,4 & 13,8 \\
\hline Overige BOL-opleidingen & 7,5 & 10,7
\end{tabular}

\section{Diepgang opleiding}

Een aanzienlijk deel van de gediplomeerden van de creatieve opleidingen vond dat hun opleiding te weinig diepgang had: drie op de tien gediplomeerden. Slechts I op de 20 gediplomeerden gaf daarentegen aan dat de opleiding te veel diepgang had. De opleidingscategorieën goud- en zilversmeden (45\%) en Theater en Podiumtechniek (44\%) hadden onder de creatieve opleidingen verreweg het grootste aandeel gediplomeerden dat de opleiding weinig diepgaand vond. Onder de gediplomeerden van de goud/zilversmeden opleidingen uit zich dit ook in een laag percentage dat de opleiding juist te diepgaand vond (3\%). Onder de gediplomeerden Theater en Podiumtechniek vond men met $9 \%$ echter ook relatief het vaakst dat de opleiding te veel diepgang had. Ongeveer drie op de tien gediplomeerden van de overige twee opleidingscategorieën vond de opleiding te weinig diepgaand. Het omgekeerde gold voor $3 \%$ van de gediplomeerden Mode en Kleding en voor 4,5\% van de gediplomeerden Media en Grafische Vormgeving. De gediplomeerden van de overige BOL-opleidingen vonden in veel mindere mate hun opleiding te weinig diepgang hebben: $18 \%$ van hen vond dat de opleiding te weinig diepgang had en $6 \%$ vond de opleiding juist te veel diepgang hebben. Deze gediplomeerden zijn per saldo dus vaker tevreden over de diepgang van hun opleiding dan de gediplomeerden van de creatief gerichte opleidingen.

Tabel 3

Aandeel gediplomeerden dat vond dat de opleiding te weinig diepgang ( 1 of 2 op een zevenpuntsschaal) of te veel diepgang ( 6 of 7 op een zevenpuntsschaal) had

\begin{tabular}{lcc}
\hline$\%$ & te weinig diepgang & te veel diepgang \\
\hline Goud- en zilversmeden & 45,4 & 3,1 \\
\hline Mode en Kleding & 30,0 & 3,4 \\
\hline Theater en Podiumtechniek & 43,9 & 9,2 \\
\hline Media en Grafische Vormgeving & 28,0 & 4,5 \\
\hline Totaal creatieve MB0-opleidingen & 30,5 & 4,7 \\
\hline Overige BOL-opleidingen & 18,0 & 6,0
\end{tabular}




\section{Starten arbeidsmarkt en verder ontwikkelen van kennis en vaardigheden}

Aan de gediplomeerden is gevraagd om op een vijfpuntsschaal (van I 'helemaal niet' $t / m 5$ 'in sterke mate') aan te geven in welke mate de gevolgde opleiding een goede basis bood om te starten op de arbeidsmarkt (startbekwaamheid) en in welke mate de gevolgde opleiding een goede basis bood voor het verder ontwikkelen van kennis en vaardigheden (ontwikkelpotentieel). Tabel 4 toont het aandeel van de BOL-gediplomeerden dat vindt dat de opleiding een goede basis biedt om te starten op de arbeidsmarkt respectievelijk om kennis en vaardigheden verder te ontwikkelen (antwoordcategorie 4 of 5). Ten eerste laat tabel 4 zien dat de gediplomeerden beter te spreken zijn over hun ontwikkelpotentieel dan over hun startbekwaamheid. Dit geldt zowel voor de creatieve opleidingen als voor de overige bol-opleidingen. Gediplomeerden van de creatieve opleidingen zijn overigens minder vaak dan gediplomeerden van de overige BOL-opleidingen positief over hun startbekwaamheid. Van alle creatieve opleidingen in het MBO zijn gediplomeerden Media en Grafische Vormgeving relatief het vaakst goed te spreken over zowel hun startbekwaamheid als hun ontwikkelpotentieel.

Tabel 4

Aandeel gediplomeerden dat de opleiding een goede basis vond om (1) te starten op de arbeidsmarkt en (2) zijn/haar kennis en vaardigheden verder te ontwikkelen ( 4 of 5 op een vijfpuntsschaal)

\begin{tabular}{lcc}
\hline$\%$ & starten arbeidsmarkt & verder ontwikkelen \\
\hline Goud- en zilversmeden & 22,8 & 46,4 \\
\hline Mode en Kleding & 23,5 & 44,7 \\
\hline Theater en Podiumtechniek & 20,6 & 44,0 \\
\hline Media en Grafische Vormgeving & 42,0 & 60,7 \\
\hline Totaal creatieve MBO-opleidingen & 36,1 & 55,8 \\
\hline Overige BOL-opleidingen & 48,0 & 58,9
\end{tabular}




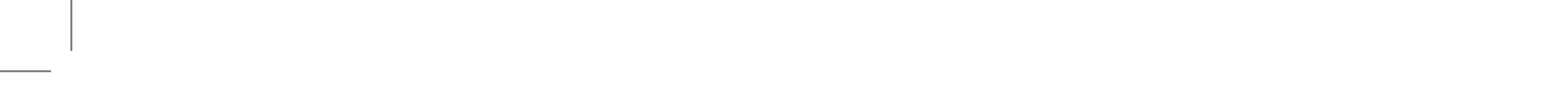




\section{Selectie}

In dit hoofdstuk worden enkele indicatoren gepresenteerd die iets zeggen over de selectiefunctie van het onderwijs. Zoals reeds eerder werd vermeld, is de betrouwbaarheid waarmee het onderwijs op competenties selecteert van wezenlijk belang. Er is aan de gediplomeerden gevraagd om over de volgende vijf aspecten hun oordeel te geven (I) de moeilijkheidsgraad van de opleiding, (2) de strengheid van de docenten bij het beoordelen van scholieren/studenten, (3) de mate waarin de opleiding uitdagend was qua niveau, (4) de mate waarin de examens als pittig werden ervaren, (5) de mate waarin op inzicht werd getoetst. We moeten ons realiseren dat het daarbij gaat om de subjectieve oordelen van gediplomeerden zelf. Bovendien wordt dit gevraagd aan degenen die de opleiding hebben afgerond en zegt het dus meer over de selectiviteit tijdens de opleiding dan over de selectiviteit bij de intrede. Niettemin geven deze indicatoren een goed beeld van de mate waarin naar het oordeel van de gediplomeerden zelf de opleiding voldoende selectief is geweest.

\section{Moeilijkheidsgraad}

Gediplomeerden van creatief gerichte opleidingen vinden hun opleiding vaker te gemakkelijk dan te moeilijk: gemiddeld vond $31 \%$ van de gediplomeerden van de creatieve opleidingen hun opleiding te gemakkelijk, terwijl slechts 3,5\% de opleiding juist te moeilijk vond. Bijna 2/3 van de gediplomeerden was dus wel tevreden over de moeilijkheidsgraad van de opleiding. De gediplomeerden van Theater en Podiumtechniek waren daarbij met $47 \%$ het vaakst van mening dat hun opleiding te gemakkelijk was, terwijl niemand van hen de opleiding te moeilijk vond. Desalniettemin vinden ook de gediplomeerden van de overige creatieve opleidingen hun opleiding veel vaker te gemakkelijk dan de gediplomeerden van de overige BOL-opleidingen, waarvan 'slechts' $22 \%$ de opleiding te gemakkelijk vond. Ook vinden de gediplomeerden van de creatieve opleidingen hun opleiding minder vaak te moeilijk dan de overige BOL-gediplomeerden, waarvan $6,5 \%$ de opleiding te moeilijk vond. Dit betekent per saldo dat zij met $72 \%$ vaker tevreden zijn over de moeilijkheidsgraad van de opleiding dan de gediplomeerden van de creatief gerichte opleidingen (66\% tevreden). 
Tabel 5

Aandeel gediplomeerden dat de opleiding respectievelijk te gemakkelijk ( 1 of 2 op een zevenpuntsschaal) dan wel te moeilijk ( 6 of 7 op een zevenpuntsschaal) vond

\begin{tabular}{lcc}
\hline$\%$ & te gemakkelijk & te moeilijk \\
\hline Goud/zilversmeden & 34,8 & 3,3 \\
\hline Mode \& Kleding & 34,6 & 4,4 \\
\hline Theater \& Podiumtechniek & 47,3 & 0,0 \\
\hline Media \& Grafische Vormgeving & 27,2 & 3,9 \\
\hline Totaal creatieve MB0-opleidingen & 30,6 & 3,6 \\
\hline Overige BOL-opleidingen & 21,8 & 6,5
\end{tabular}

\section{Strenge beoordeling van studenten}

Gemiddeld vond zo'n $20 \%$ van de gediplomeerden van de creatieve opleidingen dat de docenten tijdens hun opleiding streng waren in de beoordeling. Gediplomeerden van de opleidingen goud/zilversmeden vonden de docenten tijdens hun opleiding het vaakst streng: $28 \%$ van hen gaf dit aan, terwijl slechts $6 \%$ van de gediplomeerden van opleidingen Theater \& Podiumtechniek zijn/haar docenten streng vond tijdens de opleiding. Bij de gediplomeerden van de overige BOL-opleidingen was $18 \%$ van mening dat de docenten streng in de beoordeling waren.

Tabel 6

Aandeel gediplomeerden dat vond dat de docenten streng waren in de beoordeling van studenten tijdens de opleiding ( 4 of 5 op een vijfpuntsschaal)

\begin{tabular}{|lc}
\hline$\%$ & streng in beoordeling \\
\hline Goud- en zilversmeden & 27,6 \\
\hline Mode en Kleding & 17,3 \\
\hline Theater en Podiumtechniek & 5,7 \\
\hline Media en Grafische Vormgeving & 21,4 \\
\hline Totaal creatieve MBO-opleidingen & 19,5 \\
\hline Overige BOL-opleidingen & 18,2 \\
\hline
\end{tabular}

\section{Opleiding heeft een uitdagend niveau}

Drie op de tien gediplomeerden van de creatieve opleidingen vond de gevolgde opleiding uitdagend qua niveau. Daarmee verschillen de gediplomeerden van de creatieve opleidingen niet van de overige BOL-opleidingen (29\%). Uitzonderingen hierop zijn enerzijds de gediplomeerden van de opleidingen goud/zilversmeden die met $38 \%$ vaker van mening zijn dat hun opleiding uitdagend was en anderzijds die gediplomeerden van de Theater en Podiumtechniek opleidingen, waarvan maar $23 \%$ de opleiding uitdagend vond. 
Tabel 7

Aandeel gediplomeerden dat de opleiding uitdagend qua niveau vond ( 4 of 5 op een vijfpuntsschaal)

\begin{tabular}{lc}
\hline$\%$ & uitdagend qua niveau \\
\hline Goud- en zilversmeden & 38,1 \\
\hline Mode en Kleding & 27,8 \\
\hline Theater en Podiumtechniek & 23,1 \\
\hline Media en Grafische Vormgeving & 30,8 \\
\hline Totaal creatieve MBO-opleidingen & 29,9 \\
\hline Overige BOL-opleidingen & 29,1
\end{tabular}

\section{Examens/opdrachten over het algemeen van pittig niveau}

$22 \%$ van de gediplomeerden van de creatieve opleidingen vond de examens en opdrachten tijdens de opleiding van pittig niveau. Dit is overigens bijna hetzelfde als bij de gediplomeerden van de overige BOL-opleidingen (24\%). Het overgrote merendeel vond de examens en opdrachten dus gemakkelijk. Onder de gediplomeerden van de opleidingen Goud- en zilversmeden is men vaker van mening dat de examens en opdrachten van pittig niveau waren. $35 \%$ van de gediplomeerden gaf dit aan. Gediplomeerden van Media en Grafische Vormgeving beoordeelden hun examens en opdrachten het minst vaak als pittig: een op de vijf van hen deed dit.

Tabel 8

Aandeel gediplomeerden dat de examens en opdrachten in de opleiding van pittig niveau vond

\begin{tabular}{lc}
\hline$\%$ & examens pittig \\
\hline Goud- en zilversmeden & 34,7 \\
\hline Mode en Kleding & 26,6 \\
\hline Theater en Podiumtechniek & 28,1 \\
\hline Media en Grafische Vormgeving & 20,0 \\
\hline Totaal creatieve MBO-opleidingen & 22,4 \\
\hline Overige BOL-opleidingen & 24,2
\end{tabular}

\section{Toetsen op inzicht}

$29 \%$ van de gediplomeerden van de creatieve opleidingen geeft aan dat er tijdens de opleiding op inzicht getoetst werd. In de overige BOL-opleidingen gebeurt dit iets vaker: hier geeft $35 \%$ van de gediplomeerden aan dat er getoetst werd op inzicht. Tussen de verschillende soorten creatieve opleidingen is er weinig verschil. De gediplomeerden van de opleidingen Goud- en zilversmeden geven het minst vaak aan dat er tijdens hun opleiding minder vaak op inzicht getoetst werd. $21 \%$ van hen gaf dit aan. 
HOOFDSTUK 4

Tabel 9

Aandeel gediplomeerden dat aangeeft dat er tijdens de opleiding op inzicht getoetst werd

\begin{tabular}{lc}
\hline$\%$ & toetsen op inzicht \\
\hline Goud- en zilversmeden & 20,6 \\
\hline Mode en Kleding & 29,5 \\
\hline Theater en Podiumtechniek & 32,8 \\
\hline Media en Grafische Vormgeving & 28,1 \\
\hline Totaal creatieve MBO-opleidingen & 28,5 \\
\hline Overige BOL-opleidingen & 34,5 \\
\hline
\end{tabular}




\section{Kwalificerende vervolgtrajecten}

$\mathrm{Al}$ voor het behalen van het diploma staan gediplomeerden voor een belangrijke keuze. Men kan toetreden tot de arbeidsmarkt of kiezen voor een vervolgtraject in het onderwijs. Omdat deze vervolgtrajecten verschillend van karakter zijn worden deze groepen om de allocatiefunctie in kaart te brengen apart behandeld. In dit hoofdstuk gaat het om de uitstroom die kiest voor een vervolgstudie.

\subsection{Allocatie}

Meer dan de helft van de gediplomeerden van de creatieve opleidingen is een vervolgopleiding gaan volgen. $56 \%$ van hen ging verder leren. Het overgrote merendeel van hen is dit gaan doen in een HBO-opleiding (48\%), nog $7 \%$ is wederom een BOL-opleiding gaan volgen. I\% koos voor een BBL-vervolgopleiding. Van de gediplomeerden Media en Grafische Vormgeving ging maar liefst 54\% een HBO-opleiding volgen, terwijl maar $42 \%$ niet voor een vervolgopleiding koos. De gediplomeerden van de opleidingscategorie Mode en Kleding kozen relatief vaak opnieuw voor een BOL-opleiding in het MBO. Ter vergelijking: van de overige BOL-gediplomeerden ging de helft een vervolgopleiding volgen, waarvan $26 \%$ in het $\mathrm{HBO}$, I $8 \%$ weer in een BOL-opleiding en $7 \%$ in een BBL-opleiding.

Tabel 10

Doorstroom gediplomeerden naar vervolgonderwijs en niveau vervolgopleiding

\begin{tabular}{lcrrrr} 
\% & geen vervolgonderwijs & BOL & BBL & HBO & WO \\
Goud- en zilversmeden & 77,3 & 7,2 & 7,2 & 3,1 & 5,2 \\
\hline Mode en Kleding & 41,3 & 19,9 & 1,2 & 37,6 & 0,0 \\
\hline Theater en Podiumtechniek & 49,4 & 14,8 & 0,0 & 35,9 & 0,0 \\
Media en Grafische Vormgeving & 41,7 & 2,8 & 1,2 & 54,3 & 0,0 \\
Totaal creatieve MBO-opleidingen & 43,8 & 7,2 & 1,3 & 47,5 & 0,2 \\
Overige BOL-opleidingen & 49,0 & 17,6 & 6,8 & 26,4 & 0,0
\end{tabular}

Tabel Io toont de belangrijkste vervolgopleidingen voor de twee grootste opleidingen (Mode en Kleding en Media en Grafische Vormgeving). Voor de doorstromers vanuit Mode en Kleding vormt de opleidingssector hbo economie het belangrijkste vervolgonderwijs. Opleidingen waar deze gediplomeerden voor hebben gekozen zijn o.a. HBO Fashion, HBO Modemanagement, HBO Communicatie, HBO Fashion 
Design en HBO Technische commerciële textielkunde. Voor de doorstromers vanuit Media en Grafische Vormgeving is dit de opleidingssector HBO Taal en Cultuur. Veel gekozen opleidingen onder hen zijn: HBO Graphic Design, HBO Communicatie en HBO Communication en Multimedia Design.

\section{Tabel 11}

Belangrijkste sectoren vervolgopleidingen (aandeel minimaal 5\%)

\begin{tabular}{lr|}
\hline Mode en Kleding & 5 \\
\hline BOL niveau $1 / 2$ techniek & 15 \\
\hline BOL niveau $3 / 4$ techniek & 5 \\
\hline BOL niveau $3 / 4$ gezondheidszorg & 8 \\
\hline HBO techniek & 33 \\
\hline HBO economie & 8 \\
\hline HBO gedrag en maatschappij & 12 \\
\hline HBO taal en cultuur & 18 \\
\hline Media en Grafische Vormgeving & 26 \\
\hline HBO techniek & 5 \\
\hline HBO economie & 41 \\
\hline HBO gedrag en maatschappij & \\
\hline HBO taal en cultuur &
\end{tabular}

Van de gediplomeerden van de creatieve BOL-opleidingen die vervolgonderwijs zijn gaan volgen, deed slechts $24 \%$ dit in een verwante opleidingsrichting. Dit kan een signaal zijn dat zij mogelijk in een andere opleidingsrichting betere arbeidsmarktperspectieven zien. Een andere mogelijke verklaring is het feit dat de meest logische verwante vervolgopleiding voor sommige gediplomeerden een kunstopleiding in het $\mathrm{HBO}$ is. Deze opleidingen kennen doorgaans een zeer strenge selectie aan de poort. Gediplomeerden van creatieve MBO-opleidingen (op niveau 4) zullen zeker niet per definitie worden toegelaten tot deze HBO kunstopleidingen. Onder de gediplomeerden van de overige BOL-opleidingen ging een veel groter deel van de doorlerenden naar een verwante vervolgopleiding: $2 / 3$ van hen deed dit. Daartegenover staan de $24 \%$ van de gediplomeerden uit de Media en Grafische Vormgeving, en de $27,5 \%$ van de gediplomeerden Mode en Kleding in schril contrast.

Tabel 12

Aandeel gediplomeerden met vervolgonderwijs, waarvan dit in een verwante opleidingsrichting is

\begin{tabular}{lcc}
\hline$\%$ & verwant vervolgonderwijs & goede aansluiting \\
\hline Goud- en zilversmeden & $\mathrm{x}$ & $\mathrm{x}$ \\
\hline Mode en Kleding & 27,5 & 62,7 \\
\hline Theater en Podiumtechniek & $\mathrm{x}$ & $\mathrm{x}$ \\
\hline Media en Grafische Vormgeving & 23,6 & 62,8 \\
\hline Totaal creatieve MBO-opleidingen & 24,0 & 60,6 \\
\hline Overige BOL-opleidingen & 65,6 & 71,6 \\
$\mathrm{x}=$ te weinig waarnemingen & &
\end{tabular}


Aanzienlijk meer gediplomeerden van de creatieve opleidingen zijn te spreken over de aansluiting tussen hun gevolgde opleiding en hun vervolgopleiding, ondanks de geringe verwantheid zoals uit tabel ro bleek. $61 \%$ beoordeelt de aansluiting tussen gevolgde opleiding en vervolgopleiding als goed. Toch zijn zij daarmee nog steeds minder vaak tevreden over de aansluiting met hun vervolgopleiding dan andere BOL-gediplomeerden die voor een vervolgopleiding hebben gekozen. Van hen noemt $72 \%$ de aansluiting goed.

\subsection{Rendement}

Zoals reeds eerder ter sprake is gekomen is een van de functies van het onderwijs het voorbereiden van leerlingen op een eventueel vervolgtraject in het onderwijs. Om het rendement hiervan te meten, kijken we naar het percentage dat op het moment van enquêteren (ongeveer anderhalf jaar na het behalen van het diploma) in de vervolgopleiding bevorderd is naar het tweede leerjaar/studiejaar en het percentage dat de vervolgopleiding op het moment van de enquête weer heeft verlaten of van studie is gewisseld. Een grote uitval in het vervolgonderwijs kan duiden op een gebrekkige aansluiting. Deze gebrekkige aansluiting kan meerdere oorzaken hebben. Zo kan het curriculum van één of beide opleidingen niet passend (genoeg) zijn. Daarnaast kan er sprake zijn van een gebrekkige studiekeuzevoorlichting of kan de arbeidsmarkt veel mogelijkheden bieden.

Als we naar het presteren in de vervolgopleiding van de doorstromers naar vervolgonderwijs kijken, dan zien we dat ruim $80 \%$ van de doorstromers na circa anderhalf jaar nog steeds bezig is met de vervolgopleiding. Dit geldt zowel voor doorstromers vanuit creatieve opleidingen in het mbo-bol als voor doorstromers vanuit andere opleidingen in het mbo-bol. Bij de creatieve opleidingen is $15 \%$ gestopt, waarvan 6\%-punt definitief met het onderwijs is gestopt; bij de andere BOL-opleidingen is II\% gestopt maar daarvan stopte slechts 3\%-punt definitief. Van de gediplomeerden die de vervolgopleiding hebben beëindigd, hebben gediplomeerden Media en Grafische Vormgeving veel vaker het onderwijs verlaten (8\%) dan gediplomeerden Mode en Kleding (I\%), die op hun beurt wel vaker van vervolgopleiding zijn gewisseld (I6\% tegenover $7 \%$ ).

Tabel 13

Huidige situatie gediplomeerden die een vervolgopleiding zijn gaan volgen

\begin{tabular}{lcccc}
\hline$\%$ & $\begin{array}{c}\text { volgt opleiding } \\
\text { nog steeds }\end{array}$ & $\begin{array}{c}\text { diploma/ } \\
\text { deelcertificaat } \\
\text { behaald }\end{array}$ & studiewisselaars & uitval \\
\hline Goud- en zilversmeden & 75,0 & 0,0 & $\mathrm{X}$ & $\mathrm{X}$ \\
\hline Mode en Kleding & 82,0 & 1,1 & 15,8 & 1,1 \\
\hline Theater en Podiumtechniek & $\mathrm{x}$ & $\mathrm{x}$ & $\mathrm{x}$ & $\mathrm{x}$ \\
\hline Media en Grafische Vormgeving & 81,6 & 3,5 & 7,1 & 7,8 \\
\hline Totaal creatieve MBO-opleidingen & 81,9 & 3,0 & 9,0 & 6,2 \\
\hline Overige BOL-opleidingen & 84,3 & 4,7 & 7,8 & 3,2 \\
\hline x = te weinig waarnemingen & & & &
\end{tabular}


$78 \%$ van de gediplomeerden van de creatieve opleidingen zijn inmiddels bevorderd naar het tweede leerjaar van hun vervolgopleiding. Als we dit vergelijken met de $82 \%$ uit tabel II die hun vervolgopleiding nog steeds volgen dan is verreweg het grootste deel van hen bevorderd naar het tweede leerjaar. Er is hierbij weinig verschil tussen gediplomeerden van Mode en Kleding, en gediplomeerden van Media en Grafische Vormgeving. Gediplomeerden van de overige BOL-opleidingen met vervolgonderwijs zijn anderhalf jaar na het behalen van hun diploma iets vaker bevorderd naar het tweede leerjaar.

\section{Tabel 14}

Aandeel gediplomeerden met vervolgonderwijs die bevorderd zijn naar het tweede leerjaar

\begin{tabular}{lc}
\hline$\%$ & bevorderd naar 2e leerjaar \\
\hline Goud- en zilversmeden & $\mathrm{x}$ \\
\hline Mode en Kleding & $\mathrm{X}, 4$ \\
\hline Theater en Podiumtechniek & 78,9 \\
\hline Media en Grafische Vormgeving & 78,3 \\
\hline Totaal creatieve MB0-opleidingen & 84,4 \\
\hline Overige BOL-opleidingen & \\
x = te weinig waarnemingen &
\end{tabular}




\section{Intrede op de arbeidsmarkt}

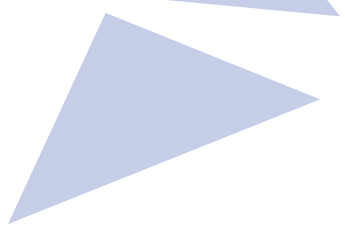

Het onderwijs wordt geacht leerlingen kennis en vaardigheden bij te brengen die ze nodig hebben in eventueel vervolgonderwijs of op de arbeidsmarkt. Het vorige hoofdstuk richtte zich op de verder lerende gediplomeerden, in dit hoofdstuk staat de groep centraal die de arbeidsmarkt betreden heeft. Aan de hand van de oordelen van de gediplomeerden en hun baankenmerken wordt een indicatie verkregen over de allocatiefunctie van het onderwijs voor zover het de doorstroom naar de arbeidsmarkt betreft. Daarnaast komt het extern rendement aan bod. De groep gediplomeerden die daarbij centraal staat bestaat uit de gediplomeerde schoolverlaters die op het moment van ondervraging tot de beroepsbevolking worden gerekend en die tevens aangeven dat hun maatschappelijke positie niet scholier of student is. Deze laatste voorwaarde geldt om te voorkomen dat studenten met bijbaantjes in de analyses terecht komen.

\subsection{Allocatie}

In eerste instantie valt of staat een succesvolle intrede op de arbeidsmarkt met het al dan niet vinden van een baan. De feitelijke werkzaamheden, verantwoordelijkheden en de inhoud van de functie bepalen in hoeverre iemand de mogelijkheid heeft om zijn of haar kennis en vaardigheden te benutten. Daarnaast bepalen de inhoud en het niveau van het werk de financiële vergoeding die hier tegenover staat. Dus niet alleen de werkzekerheid maar ook de kwaliteit van werk heeft invloed op een succesvolle overgang van onderwijs naar arbeidsmarkt. Beginners op de arbeidsmarkt zullen vaak in startfuncties terecht komen. Ook voor deze startfuncties geldt dat voor individuen de kwaliteit van het werk toeneemt naarmate de gevonden baan beter aansluit op de gevolgde opleiding voor wat betreft richting en vooral niveau.

\section{Vereist opleidingsniveau en -richting}

Bijna driekwart van de betaald werkende gediplomeerden van de creatieve opleidingen is werkzaam in een functie waarvoor de werkgever minimaal een $\mathrm{MBO}$-opleiding vereiste. Dit is iets minder dan bij de gediplomeerden van de overige BOL-opleidingen, waar $78 \%$ in een functie werkzaam is waarvoor minimaal het eigen niveau vereist werd. De gediplomeerden van Media en Grafische Vormgeving zijn onder de creatieve opleidingen iets vaker minimaal op het eigen niveau werkzaam ( $76 \%)$, en de gediplomeerden van Mode en Kleding iets minder vaak: $69 \%$. 
Tabel 15

Aandeel werkende gediplomeerden dat werkzaam is in een functie waarvoor respectievelijk minimaal het eigen opleidingsniveau en de eigen of een verwante opleidingsrichting door de werkgever vereist werd

\begin{tabular}{lcc} 
\% & minimaal eigen opleidingsniveau & eigen/verwante opleidingsrichting \\
\hline Goud- en zilversmeden & $\mathrm{x}$ & $\mathrm{x}$ \\
\hline Mode en Kleding & 69,3 & 50,0 \\
\hline Theater en Podiumtechniek & $\mathrm{x}$ & $\mathrm{x}$ \\
\hline Media en Grafische Vormgeving & 75,7 & 61,3 \\
\hline Totaal creatieve MBO-opleidingen & 73,2 & 58,2 \\
\hline Overige BOL-opleidingen & 78,4 & 71,6 \\
\hline x = te weinig waarnemingen & &
\end{tabular}

De gediplomeerden werken echter minder vaak in een functie waarvoor de eigen of een verwante opleidingsrichting vereist werd door de werkgever. $58 \%$ van de werkende gediplomeerden van de creatieve opleidingen werkt in een functie waarvoor de eigen of een verwante opleidingsrichting vereist werd. Ook de gediplomeerden van de overige BOL-opleidingen werken minder vaak in een functie waarvoor de eigen of een verwante richting vereist werd, dan in een functie waarvoor minimaal het eigen niveau gevraagd werd. Met $72 \%$ is dit wel een groter deel dan onder de gediplomeerden van de creatieve opleidingen. Net als bij vereist opleidingsniveau zijn de gediplomeerden van Media en Grafische Vormgeving iets vaker binnen de eigen richting werkzaam dan de gediplomeerden van Mode en Kleding.

Van de betaald werkende gediplomeerden van de creatieve opleidingen werkt 55\% zowel minimaal op eigen niveau als binnen de eigen of een verwante opleidingsrichting. $19 \%$ werkt wel op minimaal het eigen niveau, maar dan in een andere richting. $6 \%$ werkt wel binnen de eigen opleidingsrichting, maar onder hun opleidingsniveau en $20 \%$ ten slotte, werkt zowel onder het eigen opleidingsniveau als in een functie waarvoor een andere of geen specifieke opleidingsrichting vereist werd. Bij de gediplomeerden van de overige BOL-opleidingen werkt $64 \%$ zowel minimaal op eigen niveau als binnen de eigen of een verwante opleidingsrichting. I4\% werkt wel op minimaal het eigen niveau, maar in een andere richting. $8 \%$ werkt wel binnen de eigen opleidingsrichting, maar onder hun opleidingsniveau en I4\% werkt zowel onder het eigen opleidingsniveau als in een functie waarvoor een andere of geen specifieke opleidingsrichting vereist werd.

\section{Onderbenutting dan wel tekortschieten van kennis en vaardigheden}

$56 \%$ van de werkende gediplomeerden van de creatieve opleidingen geeft aan dat zijn/haar kennis en vaardigheden voldoende benut worden in de huidige functie. Daarbij worden de kennis en vaardigheden van de gediplomeerden van Media en Grafische Vormgeving (60\%) veel vaker voldoende benut dan bij de gediplomeerden van Mode en Kleding (37\%). Van de overige BOL-gediplomeerden geeft $64 \%$ aan dat zijn/haar kennis en vaardigheden voldoende benut worden in de huidige functie. 
Onderbenutting komt dus bij redelijk wat gediplomeerden voor. Hoe zit het met het tegenovergestelde? Bij de creatieve opleidingen geeft $13 \%$ van de betaald werkende gediplomeerden aan dat hun kennis en vaardigheden tekortschieten in de huidige functie; een vergelijkbaar aandeel als bij de overige gediplomeerden (I2\%). De gediplomeerden van Media en Grafische Vormgeving geven bijna twee keer zo vaak als de gediplomeerden van Mode en Kleding aan dat hun kennis en vaardigheden tekortschieten in de huidige functie. Het valt te verwachten dat voldoende benutting van kennis en vaardigheden vooral voorkomt onder gediplomeerden die op hun niveau en binnen hun eigen domein werken. Onderbenutting en tekorten zijn vaker te verwachten bij gediplomeerden die onder hun niveau en/of buiten hun domein werkzaam zijn.

Tabel 16

Aandeel werkende gediplomeerden dat aangeeft dat hun kennis en vaardigheden (1) voldoende benut worden en (2) tekortschieten in de huidige functie ( 4 of 5 op een vijfpuntsschaal)

\begin{tabular}{lcc}
\hline$\%$ & benutting & tekort \\
Goud- en zilversmeden & $\mathrm{x}$ & $\mathrm{x}$ \\
\hline Mode en Kleding & 37,1 & 9,1 \\
\hline Theater en Podiumtechniek & $\mathrm{x}$ & $\mathrm{x}$ \\
\hline Media en Grafische Vormgeving & 59,5 & 16,8 \\
\hline Totaal creatieve MBO-opleidingen & 55,7 & 13,4 \\
\hline Overige BOL-opleidingen & 63,5 & 12,0 \\
$\mathrm{x}=$ te weinig waarnemingen & &
\end{tabular}

\section{Oordeel aansluiting opleiding-werk}

Bijna 6 op de Io betaald werkende gediplomeerden van de creatieve opleidingen vinden de aansluiting tussen hun gevolgde opleiding en hun huidige functie voldoende of goed. Andere BOL-gediplomeerden zijn gemiddeld vaker tevreden over de aansluiting tussen hun opleiding en hun huidige functie: $76 \%$ van hen vindt de aansluiting voldoende of goed. De gediplomeerden van Media en Grafische Vormgeving zijn daarbij iets vaker te spreken over de aansluiting tussen de opleiding en hun werk (64\%) dan de gediplomeerden van Mode en Kleding (59\%).

\section{Tevredenheid huidige functie}

$2 / 3$ van de betaald werkende gediplomeerden van de creatieve opleidingen is tevreden met hun huidige functie. Onder de overige BOL-gediplomeerden is dit aandeel iets hoger: $72 \%$ zegt tevreden te zijn over hun huidige baan. Gediplomeerden van Mode en Kleding en van Media en Grafische Vormgeving zijn ongeveer in dezelfde mate tevreden met hun huidige functie. 
Tabel 17

Aandeel werkende gediplomeerden dat de aansluiting tussen hun opleiding en de huidige functie voldoende of goed vindt

\begin{tabular}{lcc}
\hline$\%$ & goed of voldoende \\
\hline Goud- en zilversmeden & 59,0 & $\mathrm{X}$ \\
\hline Mode en Kleding & 64,2 \\
\hline Theater en Podiumtechniek & 58,9 \\
\hline Media en Grafische Vormgeving & 76,4 \\
\hline Totaal creatieve MBO-opleidingen & \\
\hline Overige BOL-opleidingen & \\
x = te weinig waarnemingen &
\end{tabular}

Tabel 18

Aandeel werkende gediplomeerden dat tevreden is met de huidige functie ( 4 of 5 op een vijfpuntsschaal)

\begin{tabular}{|c|c|}
\hline$\%$ & tevreden \\
\hline Goud-en zilversmeden & $x$ \\
\hline Mode en Kleding & 64,3 \\
\hline Theater en Podiumtechniek & $x$ \\
\hline Media en Grafische Vormgeving & 66,8 \\
\hline Totaal creatieve MBO-opleidingen & 66,4 \\
\hline Overige BOL-opleidingen & 72,1 \\
\hline
\end{tabular}

\subsection{Extern rendement}

Om inzicht te krijgen in het extern rendement, de doelmatigheid van het onderwijs met betrekking tot de arbeidsmarkt, wordt in de rest van deze paragraaf een aantal arbeidsmarktindicatoren voor de verschillende onderwijsniveaus naast elkaar gezet.

\section{Beroepsbevolking en werkloosheid}

Slechts $46 \%$ van de gediplomeerden van de creatieve opleidingen biedt zich anderhalf jaar na het behalen van het diploma aan op de arbeidsmarkt. Dat wil niet zeggen dat veel gediplomeerden inactief zijn. $56 \%$ is immers een vervolgopleiding gaan volgen na het afronden van de opleiding. Uitvallers in de vervolgopleiding en doorstromers naar BBL-vervolgopleidingen (die ook als arbeidsmarkt gezien worden) verklaren hierbij de som van boven de $100 \%$ van gediplomeerden die zich op de arbeidsmarkt aanbieden en die verder zijn gaan leren. Onder de overige BOL-gediplomeerden biedt een groter deel zich anderhalf jaar na het behalen van het diploma aan op de arbeidsmarkt: $60 \%$. De gediplomeerde goud/zilversmeden bieden zich het vaakst aan op de arbeidsmarkt: 82\%; de gediplomeerden van Media en Grafische Vormgeving juist het minst vaak: $44 \%$. 
Tabel 19

Aandeel gediplomeerden dat zich op de arbeidsmarkt aanbiedt en het deel hiervan dat werkloos is

\begin{tabular}{lcc}
\hline$\%$ & beroepsbevolking & werkloosheid \\
\hline Goud- en zilversmeden & 81,7 & $\mathrm{x}$ \\
\hline Mode en Kleding & 45,6 & 14,3 \\
\hline Theater en Podiumtechniek & 51,8 & $\mathrm{x}$ \\
\hline Media en Grafische Vormgeving & 43,5 & 14,8 \\
\hline Totaal creatieve MBO-opleidingen & 46,1 & 14,8 \\
\hline Overige BOL-opleidingen & 59,7 & 9,8 \\
\hline x = te weinig waarnemingen & &
\end{tabular}

Welk deel van de tot de beroepsbevolking behorende gediplomeerden is werkloos? I5\% van de gediplomeerden van de creatieve opleidingen heeft geen werk. Dit is 50\% meer dan het werkloosheidspercentage onder de overige MBO-BOL-gediplomeerden (Iо\%). Overigens is het goed mogelijk dat gediplomeerden van de creatieve opleidingen veel meer de dupe zijn van de crisis dan de overige BOL-gediplomeerden. Tussen Media en Grafische Vormgeving enerzijds en Mode en Kleding anderzijds zijn er nauwelijks verschillen qua aandeel van werkloze gediplomeerden.

\section{Zoekduur tot eerste baan}

I $2 \%$ van de gediplomeerden van de creatieve opleidingen zochten langer dan drie maanden voor zij hun eerste baan vonden. Dit is bijna twee keer zoveel als de overige gediplomeerden van MBO-BOL. Vooral de gediplomeerden van Theater en Podiumtechniek zochten vaak minstens 4 maanden naar hun eerste baan: $23 \%$ van hen had minimaal zo lang nodig. 9\% van de gediplomeerden Mode en Kleding hadden minstens 4 maanden nodig om aan een baan te komen. De gediplomeerden van de opleidingen goud/zilversmeden daarentegen hadden allemaal al werk binnen drie maanden.

\section{Tabel 20}

Aandeel gediplomeerden dat een zoekduur van 4 maanden of meer had voor het vinden van de eerste baan

\begin{tabular}{lc}
\hline$\%$ & zoekduur $>4$ maanden \\
\hline Goud- en zilversmeden & 0,0 \\
\hline Mode en Kleding & 9,3 \\
\hline Theater en Podiumtechniek & 22,8 \\
\hline Media en Grafische Vormgeving & 11,5 \\
\hline Totaal creatieve MBO-opleidingen & 11,8 \\
\hline Overige BOL-opleidingen & 6,3
\end{tabular}




\section{Soort aanstelling}

Bijna de helft van de werkende gediplomeerden van de creatieve opleidingen heeft een tijdelijk contract in de huidige functie. Hierin verschillen deze gediplomeerden nauwelijks van de gediplomeerden van de andere BOL-opleidingen. Gediplomeerden van Mode en Kleding hebben in $51 \%$ van de gevallen een tijdelijke aanstelling in hun huidige functie; gediplomeerden van Media en Grafische Vormgeving in 53\% van de gevallen.

\section{Tabel 21}

Aandeel werkende gediplomeerden met een tijdelijk contract / met een deeltijdaanstelling (minder dan 33 uur per week)

\begin{tabular}{lcc}
\hline$\%$ & tijdelijk contract & deeltijd \\
\hline Goud- en zilversmeden & $\mathrm{X}$ & $\mathrm{x}$ \\
\hline Mode en Kleding & 51,3 & 44,4 \\
\hline Theater en Podiumtechniek & $\mathrm{X}$ & $\mathrm{x}$ \\
\hline Media en Grafische Vormgeving & 52,6 & 30,2 \\
\hline Totaal creatieve MB0-opleidingen & 48,6 & 33,4 \\
\hline Overige BOL-opleidingen & 46,2 & 47,8 \\
\hline x = te weinig waarnemingen & &
\end{tabular}

I/3 van de werkende gediplomeerden van de creatieve opleidingen werkt in een deeltijdfunctie. Dit is minder vaak dan de werkende gediplomeerden van het overige BOL. Van hen werkt bijna de helft in deeltijd. De gediplomeerden van Mode en Kleding werken vaker in de deeltijd (44\%) dan de gediplomeerden van Media en Grafische Vormgeving (30\%).

\section{Beloning}

Gemiddeld verdienen de werkende gediplomeerden van de creatieve opleidingen I,5 jaar later bruto $€$ 9,2I per uur en $€$ I365 per maand. Per uur verdienen ze daarmee iets minder dan de overige BOL-gediplomeerden $(€ 9,58)$, maar per maand juist iets meer ( $€$ I338). Blijkbaar werken zij gemiddeld meer uren per week. Dat blijkt ook uit tabel 2I, waar duidelijk werd dat gediplomeerden van de creatieve opleidingen minder in deeltijd werken dan de overige BOL-gediplomeerden. De gediplomeerden van Media en Grafische Vormgeving verdienen zowel per uur als per maand gemiddeld een stuk meer dan de gediplomeerden van Mode en Kleding.

\section{Carrièreperspectieven}

$59 \%$ van de betaald werkende gediplomeerden van de creatieve opleidingen zegt goede carrièreperspectieven te hebben in de huidige functie. Dit percentage is vergelijkbaar met het percentage van de overige BOL-gediplomeerden dat van mening is goede carrièreperspectieven te hebben in de huidige functie. De gediplomeerden van Media 
en Grafische Vormgeving zien iets vaker goede carrièreperspectieven in hun huidige functie dan de gediplomeerden van Mode en Kleding.

Tabel 22

Gemiddeld bruto uurloon en maandloon van gediplomeerden

\begin{tabular}{lcc}
$€$ & uurloon & maandloon \\
\hline Goud- en zilversmeden & $\mathrm{x}$ & $\mathrm{x}$ \\
\hline Mode en Kleding & 8,73 & 1163 \\
\hline Theater en Podiumtechniek & $\mathrm{x}$ & $\mathrm{x}$ \\
\hline Media en Grafische Vormgeving & 9,30 & 1426 \\
\hline Totaal creatieve MBO-opleidingen & 9,21 & 1365 \\
\hline Overige BOL-opleidingen & 9,58 & 1338
\end{tabular}

$\mathrm{x}=$ te weinig waarnemingen

Tabel 23

Aandeel werkende gediplomeerden dat goede carrièreperspectieven in de huidige functie heeft ( 4 of 5 op een vijfpuntsschaal van 'nauwelijks carrièremogelijkheden' <-> 'heel veel carrièremogelijkheden')

\begin{tabular}{lc}
\hline$\%$ & goede carriereperspectieven \\
\hline Goud- en zilversmeden & $\mathrm{x}$ \\
\hline Mode en Kleding & 51,4 \\
\hline Theater en Podiumtechniek & $\mathrm{X}$ \\
Media en Grafische Vormgeving & 59,1 \\
\hline Totaal creatieve MB0-opleidingen & 58,8 \\
Overige BOL-opleidingen & 56,9 \\
x = te weinig waarnemingen &
\end{tabular}




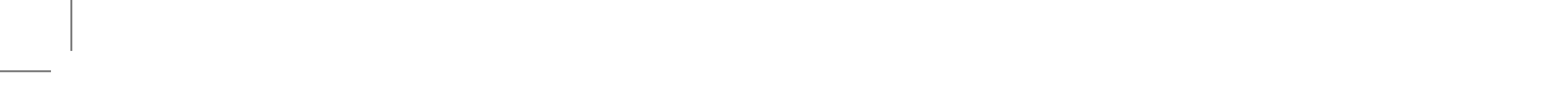




\section{Tevredenheid achteraf}

Voor de gediplomeerden van de creatieve opleidingen wordt tot slot nog gekeken in hoeverre ze de door hen gevolgde opleiding achteraf gezien opnieuw zouden kiezen.

Gemiddeld zou driekwart van de gediplomeerden van de creatieve opleidingen achteraf gezien opnieuw voor hun gevolgde opleiding kiezen. Degenen die een vervolgopleiding zijn gaan volgen $(77 \%)$ zouden iets vaker achteraf gezien weer voor dezelfde opleiding kiezen als de gediplomeerden die geen verder onderwijs zijn gaan volgen (72\%). De gediplomeerden van Media en Grafische Vormgeving zijn gemiddeld het vaakst tevreden over hun opleiding: $76 \%$. Er zijn bij hen bovendien geen verschillen tussen degenen die verder zijn gaan leren en degenen die de arbeidsmarkt hebben betreden. De gediplomeerden van Theater en Podiumtechniek zouden het minst vaak opnieuw voor hun opleiding kiezen $(70 \%)$, al is het verschil met het gemiddelde niet groot. Onder de gediplomeerden van Goud- en zilversmeden en Mode en Kleding is een vergelijkbaar deel achteraf tevreden over hun opleidingskeuze. De gediplomeerden van Mode en Kleding die de arbeidsmarkt hebben betreden zijn wel minder vaak tevreden dan degenen die een vervolgopleiding zijn gaan volgen. Onder de gediplomeerden van de overige BOL-opleidingen is een vergelijkbaar aandeel achteraf tevreden over de opleiding. Onder hen is er geen verschil tussen degenen die voor een vervolgopleiding en degenen die voor de arbeidsmarkt hebben gekozen.

Tabel 24

Aandeel gediplomeerden dat achteraf gezien voor dezelfde opleiding zou kiezen

\begin{tabular}{lccc}
\hline$\%$ & vervolgonderwijs & geen vervolgonderwijs & Totaal \\
\hline Goud- en zilversmeden & $\mathrm{x}$ & $\mathrm{x}$ & 71,3 \\
\hline Mode en Kleding & 73,5 & 66,2 & 70,5 \\
\hline Theater en Podiumtechniek & $\mathrm{x}$ & $\mathrm{x}$ & 69,6 \\
\hline Media en Grafische Vormgeving & 76,0 & 76,8 & 76,3 \\
\hline Totaal creatieve MB0-opleidingen & 76,6 & 71,5 & 74,5 \\
\hline Overige BOL-opleidingen & 76,7 & 77,0 & 76,8 \\
\hline x = te weinig waarnemingen & & &
\end{tabular}




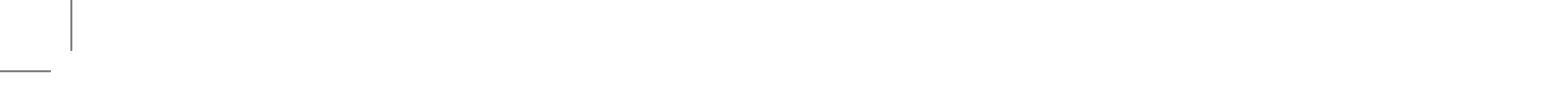




\section{Literatuur}

Onderwijsraad (1999), Schoolkwaliteit in beeld, Den Haag: Onderwijsraad.

Peschar, J., Wesselingh, A. (2001), Onderwijssociologie, Groningen: Wolters-Noordhoff.

ROA (2010), Schoolverlaters tussen onderwijs en arbeidsmarkt 2009, Maastricht: ROA. 


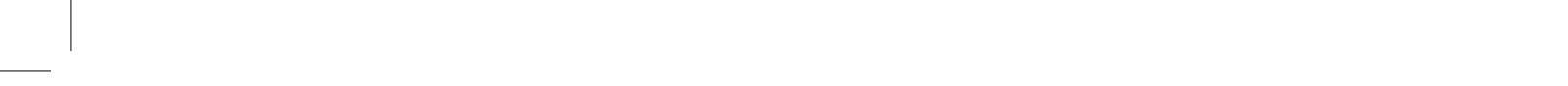

